\title{
PROPOSTA DE ALTERAÇÃO DA LEI DE ASSISTÊNCIA JUDICIÁRIA
}

\author{
Walter Piva Rodrigues \\ Professor Doutor do Departamento de Direito Processual e Mestre em Direito \\ Tributário da Faculdade de Direito da Universidade de São Paulo
}

\author{
Augusto Tavares Rosa Marcacini* \\ Mestre em Direito Processual pela Faculdade de Direito da Univerdade de São Paulo
}

\begin{abstract}
Resumo:
O artigo ensejou palestra proferida pelos autores durante Semana de Estudos Jurídicos promovida pelo Departamento Jurídico do Centro Acadêmico XI de Agosto da Faculdade de Direito da USP. O referido artigo embasa, ainda, a divulgação de anteprojeto de lei, reproduzido a final do artigo, para adaptar a atual lei, em vigor desde 1950, em matéria de assistência judiciária. Sua substituição por uma nova lei não-só está sendo necessária por força de leituras jurisprudenciais mas, ainda, pelo fato de que houve profundas alterações na dinâmica de acesso à Justiça, tendo em vista nova tábua de direitos e garantias processuais, assegurados pela Constituição de 1988.
\end{abstract}

\begin{abstract}
:
This article is a brief of a lecture by the authors during an official event promoved by the Law Office of USP Law School's Student Council. It is a general comment about a draft law concerning Legal Aid proposed in that opportunity to substitute the law that rules this subject. Legal Aid in Brazil is regulated since 1950 by a federal law that has been changed several times. In the opinion of the authors, the actual law should be reviewed deeply in order to better assure the new rights established in 1988 by the new Constitution. The proposed draft law is reproduced by the end of the article.
\end{abstract}

Unitermos: assistência judiciária; justiça gratuita; assistência jurídica integral e gratuita à população carente; acesso à Justiça; defensoria pública.

* Este co-autor do presente artigo apresentou à FDUSP, em 1993, Dissertação de Mestrado sobre o tema "Assistência Jurídica, Assistência Judiciária e Justiça Gratuita", sob orientação do Prof. Dr. Luiz Carlos de Azevedo. 


\section{Apresentação}

O texto que se segue representa a síntese das exposições feitas pelos seus subscritores na IV Jornada de Direito Processual, organizada pelo Departamento Jurídico do Centro Acadêmico XI de Agosto, e realizada no Salão Nobre da Faculdade de Direito da Universidade de São Paulo, entre 6 e 10 de outubro de 1997. Neste evento foi, pela primeira vez, tornado público o Anteprojeto de Lei de Assistência Jurídica Integral e Gratuita que aqui é exposto. Com a intenção de ampliar o debate sobre a Assistência Jurídica e sobre o anteprojeto vem à luz, agora, o presente artigo, juntamente com o nosso convite para que o leitor apresente suas críticas ou sugestões. $\mathrm{O}$ interessado poderá fazê-lo por carta, dirigida à "Mesa de Debates sobre Assistência Jurídica à População Carente", Departamento de Direito Processual da Faculdade de Direito da Universidade de São Paulo, Rua Riachuelo, 185, $5^{\circ}$ andar, São Paulo (SP), ou pelo correio eletrônico, enviando-a para mrcacini@usp.br.

\section{Histórico do anteprojeto}

Desde 1993, por iniciativa conjunta do Departamento de Direito Processual da Faculdade de Direito da Universidade de São Paulo e do Departamento Jurídico do Centro Acadêmico XI de Agosto, foi instaurada a "Mesa de Debates sobre Assistência Jurídica à População Carente" reunindo professores, alunos de graduação e pós-graduação desta Faculdade, para estudo dos temas e problemas relativos à prestação de assistência jurídica. E, como fruto das atividades da Mesa, resolveu-se elaborar um anteprojeto de lei, em substituição a atual Lei $n$. $1.060 / 50$.

Feito o esboço inicial, o anteprojeto foi objeto de discussão entre os integrantes da Mesa, resultando no trabalho que segue ao final deste artigo.

3. A necessidade da Lei $n$. $1.060 / 50$

No momento atual, em que a legislação processual passa por significativa reforma, na busca de um processo melhor e mais justo, oportuna se mostra a revisão da nossa velha Lei de Assistência Judiciária. E o que não faltam são motivos para alterá-la. 
Editada sob a égide do Código de 1939 que regulava custas e sucumbência de modo diverso do sistema atual alguns dos dispositivos da LAJ que ainda mantêm redação original só fazem sentido no contexto daquele sistema. Este é o caso, por exemplo, dos $\S \S$ do art. 11 e do art. 12.

Quem lê o $\S 1^{\circ}$, do art. 11, sem prestar atenção ao siștema contemporâneo à edição da lei, pode pensar que o legislador quis, propositadamente, que os honorários de sucumbência, em favor do advogado do beneficiário, fossem inferiores ao teto de $20 \%$ estabelecido no sistema atual. Ora, naquela época não havia regra semelhante à do art. $20, \S 3^{\circ}$, do Código vigente, estabelecendo que os honorários serão arbitrados entre $10 \%$ e $20 \%$ do valor da condenação. O princípio pelo qual o vencido deva, sempre, pagar os honorários do advogado da parte contrária só viria à luz com a edição da Lei n. 4.632/65. Até então, pelo texto original do Código de 39, o pagamento de honorários era restrito aos casos em que a parte agisse de modo temerário, quando a ação resultasse de dolo ou culpa, ou, ainda, nos casos de "absolvição da instância" E só em 1973 a lei viria a estabelecer que os honorários devem oscilar entre $10 \%$ e $20 \%$.

$\mathrm{O} \S 2^{\circ}$ deste mesmo artigo, visto no contexto atual, parece não ter sentido, ou ser fruto de erro de grafia, trocando-se "vencido" por "vencedor". Mas não é, e por estranho que pareça, fazia sentido em 1950.

$\mathrm{O}$ art. 12, por sua vez, ao suspender a exigibilidade do pagamento das verbas de sucumbência, fala apenas em "custas", pois a condenação a honorários, no sistema anterior, não era a regra. Hoje, tendo sido generalizada a condenação dọ vencido a custas e honorários, não se pode pensar que só das primeiras o carente está dispensado, porque apenas delas trata a lei.

Outro fator a estimular uma revisão da LAJ é o fato de que este diploma se encontra hoje muito emendado, e algumas das alterações feitas comprometeram sua coerência, ou interna, ou com o sistema processual. Em sua redação original, o art. $4^{\circ}$ exigia a instrução do pedido de gratuidade com a exibição de atestado de pobreza. Por isso, o art. $6^{\circ}$ ao tratar do pedido feito no curso da ação, faz menção às provas da condição de necessitado. Com o tempo, o art. $4^{\circ}$ foi sendo modificado, até atingir a redação atual, segundo a qual a mera declaração da parte é bastante para a obtenção do benefício. Mas o art. $6^{\circ}$ foi esquecido, dando a impressão de que o pedido feito ao longo do processo precise ser instruído, o que é ilógico. Igualmente, no nosso modo de ver, o recurso de apelação previsto na lei para atacar a decisão que concede ou denega a gratuidade está em desacordo com o 
sistema do Código, embora o art. 17 tenha sido alterado pela Lei n. 6.014/73, que adaptava ao novo sistema processual várias leis extravagantes.

Por último, as idéias em torno do benefício evoluíram. Nossa Constituição atual promete uma "assistência jurídica integral e gratuita", o que vai além da mera gratuidade processual ou da assistência judiciária, regidas na Lei $\mathrm{n}$. 1.060/50. Esta lei confunde os conceitos de justiça gratuita e assistência judiciária e, não raro, os intérpretes do Direito não distinguem destes dois primeiros o novo conceito contido na Constituição. Em especial, muito se discute se o art. $5^{\circ}$, inciso LXXIV, da Constituição, ao falar em comprovação da insuficiência de recursos, teria revogado a Lei n. 1.060/50, no que tange a suficiência da mera declaração de pobreza, para obtenção do benefício. Os que assim pensam, data venia, não-só confundem os conceitos de assistência jurídica integral e de justiça gratuita, como ainda, no âmbito da Justiça Estadual, ignoram o texto da Constituição do Estado de São Paulo, cujo art. $3^{\circ}$ reza:

"O Estado prestará assistência jurídica integral e gratuita aos que 'declararem' insuficiência de recursos" (grifamos)

Estes pontos acima enunciados, por vezes, desaguam em questões processuais controvertidas, que impedem ou embaraçam a concessão do benefício ou a defesa do assistido.

Estas são as razões a motivar uma revisão da Lei de Assistência Judiciária. E, mais do que novas emendas ao seu texto, que já parece uma colcha de retalhos, melhor seria uma nova lei. Propomos, então, em substituição, este anteprojeto, trazido adiante.

Em linhas gerais, o anteprojeto procura consolidar os pontos positivos da LAJ e das interpretações jurisprudenciais que se fizeram sobre ela, além de tornar mais precisos os aspectos procedimentais de concessão da gratuidade. E, indo um pouco além, o anteprojeto sugere também algumas novidades, bastante oportunas. 


\section{Comentários ao anteprojeto}

\subsection{Aspectos gerais}

O anteprojeto é dividido em três títulos. O primeiro, "Da Assistência Jurídica Integral e Gratuita", contém disposições gerais e define quem faz jus ao benefício. O segundo título, "Da Justiça Gratuita" cuida da concessão da gratuidade processual, ficando o terceiro, "Da Assistência Jurídica", encarregado de regular a forma da prestação de serviços jurídicos, judiciais ou extrajudiciais, ao carente de recursos.

\subsection{Da assistência jurídica integral e gratuita.}

Neste primeiro título, encontramos cinco pontos principais, que merecem destaque:

Em primeiro lugar, o projeto esclarece que a Assistência Jurídica Integral compreende a "Justiça Gratuita" e a "Assistência Jurídica" buscando superar a confusão conceitual existente na atual lei (art. $1^{\circ} \S$ único).

Em segundo lugar, vê-se o deslocamento do Poder Público Municipal, da posição de mero colaborador ocupada na Lei n. 1.060/50, para a posição de devedor principal da prestação de assistência jurídica integral e gratuita. A Constituição Federal, ao dizer que "o Estado prestará assistência jurídica integral e gratuita aos que comprovarem insuficiência de recursos" (art. 5, LXXIV), certamente fala em "Estado" como ente político, o que abarca todas as três esferas administrativas. Tal é, inclusive, a posição de José Carlos Barbosa Moreira, que, em seu artigo intitulado "O Direito à Assistência Jurídica: Evolução do Ordenamento Brasileiro de Nosso Tempo" (in Revista de Processo n. 67, pp. 124 a 134), assim interpreta esta promessa constitucional:

Examinemos o texto: "O Estado prestará assistência juridica integral e gratuita aos que comprovarem insuficiência de recursos" A primeira observação, um tanto óbvia, é a de que "Estado" designa aí, como em muitos outros dispositivos (v.g., arts. 5\%, LXXIII, 196, $205,215,217,218,226,227,230)$, toda e qualquer 
entidade político-administrativa: não apenas a União e os Estados-membros. Também o Município, p. ex., no âmbito próprio de sua atuação, tem o dever de assistir, e também em face dele poder surgir para o necessitado, nesse âmbito, a pretensão à assistência. Pouco importa que só a União, os Estados e o Distrito Federal sejam competentes para legislar sobre "assistência jurídica e defensoria pública" (art. 24, XIII): não há confundir competência legislativa e competência administrativa, que nem sempre coincidem.

Quis a Constituição individualizar o órgão a que incumbirão "a orientação e a defesa, em todos os graus, dos necessitados, na forma do art. $5^{\circ}$ LXXIV". conferiu tais atribuições à Defensoria Pública, cuja existência se tornou obrigatória na União, no Distrito Federal, nos Territórios e nos Estados (art. 134 e seu § único). Dai tampouco se tira argumento capaz de excluir para os Municípios o dever de assistir, até porque - como adiante se ressaltará - as atribuições mencionadas não esgotam o âmbito da "assistência jurídica integral"

Em terceiro lugar, temos a inclusão das Faculdades de Direito públicas e privadas como colaboradoras dos Poderes Públicos para promover o acesso à justiça; diante da atual exigência curricular da disciplina de Prática Jurídica, a ser ministrada obrigatoriamente pelas Faculdades de Direito, o texto proposto estimula uma sintonia entre esta atividade acadêmica e a prestação de assistência à população carente (art. $2^{\circ}$ ).

O quarto ponto a destacar é a determinação para a criação de um fundo, que terá como fonte, no mínimo, $1 \%$ das custas judiciais, para custear os benefícios instituídos no anteprojeto $\left(\right.$ art. $3^{\circ}$ ).

Em quinto e último lugar, as pessoas jurídicas foram expressamente incluídas como possíveis beneficiárias da gratuidade, atendidos os requisitos do anteprojeto (art. $4^{\circ}$, II); para não engessar as possibilidades de concessão de gratuidade processual, o art. $5^{\circ}, \S 3^{\circ}$, prevê concessão parcial do benefício para as 
pessoas não definidas expressamente no art. $4^{\circ}$, dando margem para que o juiz, caso a caso, defira o benefício para permitir o acesso à justiça.

\subsection{Da justiça gratuita}

Fiel à divisão de conceitos, neste segundo título o anteprojeto regula tão-somente a concessão da gratuidade processual.

No primeiro capítulo, é definida a extensão do benefício, começando por distinguir seus dois efeitos: a dispensa de antecipação das despesas processuais e a suspensão da exigibilidade das verbas decorrentes da sucumbência. Segue-se um rol de despesas cuja antecipação é dispensada, a título meramente exemplificativo, apenas para não deixar dúvidas a seu respeito. Foram incluídas verbas freqüentemente controvertidas, além das já-mencionadas na atual lei, com o intuito de pôr fim às discussões em torno de sua dispensa ou-não. Mas não se trata de enumeração taxativa, como se depreende do inciso $\mathrm{X}$, que dispensa o beneficiário de "todas as demais despesas, cujo pagamento seja necessário para o exercício do direito de ação ou defesa, para a produção de prova, para a prática de atos processuais ou para lhes dar eficácia"

Este inciso $X$, na verdade, encerra o verdadeiro significado do benefício da gratuidade processual. O pobre deve ser dispensado de todas as despesas decorrentes de sua participação no processo. De nada adiantaria isentar o pobre do pagamento da taxa judiciária, permitindo o ingresso em juízo, se, depois, para bem atuar no processo necessitar gastar o dinheiro que não tem. Entendido o acesso à justiça não apenas como a possibilidade de estar em juízo, mas como "acesso à ordem jurídica justa", não se justifica exigir do pobre qualquer pagamento necessário à sua boa atuação no processo. É irrelevante, até, distinguir quem é o credor desta despesa. Pode ser o próprio Poder Público, como podem ser os cartórios extrajudiciais, ou qualquer particular. Todos têm o dever de colaborar com a realização da justiça, guardadas as possibilidades de cada um. Como, entretanto, o devedor principal da gratuidade processual é o Estado, resta ao particular cobrá-lo regressivamente. É o que estabelece o art. $9^{\circ}, \S 5^{\circ}$ dando ao particular título executivo judicial para ressarcir-se das despesas que teve ou dos créditos que deixou de receber, em virtude da dispensa concedida ao assistido. O mesmo se dá quanto aos honorários do advogado do assistido, que podem ser cobrados do Estado, nos termos do $\S 6^{\circ}$. deste mesmo artigo. 
$\mathrm{O}$ art. $6^{\circ}$ amplia expressamente o conceito da gratuidade processual, que não se restringe à dispensa de pagamentos, mas pode também, dadas as necessidades do caso concreto, constituir-se de um fazer por parte do Estado ou do particular. A regra se inspirou na necessidade das partes, que moram no interior, de se deslocarem para a Capital ou centros maiores, para realizar exames sangüíneos, situação que é bastante freqüente em ações declaratórias de paternidade. De que adianta poder fazer o exame técnico gratuitamente se o pobre sequer pode custear a passagem de ônibus para levá-lo ao local? Por isso, a regra permite ao juiz, caso a caso, determinar as providências necessárias para superar o óbice encontrado pela ' parte para atuar no processo, seja ele qual for, assegurado ao particular o direito de regresso contra o Estado.

No segundo capítulo deste título, é regulado o procedimento de concessão da gratuidade processual.

$\mathrm{O}$ art. 10 dispõe que o pedido não depende de forma expressa, nem de petição autônoma, podendo ser formulado conjuntamente com qualquer ato processual, nos próprios autos do processo. E, para sua concessão, em qualquer momento processual, basta apenas a declaração do postulante de que é necessitado, afirmação esta que se presume verdadeira.

Como novidade, o art. 11 exige que o juiz, tendo dúvidas quanto ao cabimento do benefício, peça esclarecimentos ao postulante, antes de indeferir o pedido. Muitas vezes, tem o juiz razoáveis dúvidas acerca do cabimento do benefício, diante das aparências que o caso encerra; entretanto, deve ser dada ao beneficiário a oportunidade de esclarecê-las, já que, para requerer a gratuidade, não teve ele a obrigação de expor fundamentadamente sua situação patrimonial. A regra evita que o benefício seja indeferido de plano, diante de situações aparentes que não representem a realidade. Evidentemente, este pedido de esclarecimentos complementares só terá lugar quando, pelo conteúdo dos autos, existir algum elemento a levantar suspeita sobre a capacidade econômica do assistido, devendo o juiz, neste caso, fundamentar sua decisão com a exposição dos motivos que ensejaram a sua dúvida. Não pode a exigência tornar-se regra, sob pena de dificultar o acesso à justiça do necessitado.

Nos arts. 12 a 15, há a descrição de um breve procedimento para a impugnação do benefício pela parte contrária, admitida inclusive a realização de audiência para colheita de prova oral, caso se faça necessário. 
O art. 16 define os efeitos da decisão concessiva da gratuidade. Tendo natureza declaratória (reconhece a condição legal de necessitado), e não constitutiva, a decisão concessiva atinge inclusive custas ainda não pagas, mas referentes a fatos ou atos anteriores à sua concessão.

Os recursos e seus efeitos estão definidos nos arts. 17 a 20 . Não se admite recurso contra a decisão que concede de plano o benefício. Isto porque tal decisão foi fundada exclusivamente na presunção de veracidade da declaração prestada pelo beneficiário, sem ouvir-se eventuais argumentos da parte contrária. $\mathrm{O}$ recurso contra tal decisão levaria ao órgão superior matéria não-apreciada pelo juiz da causa. Portanto, neste caso, deve a parte contrária, em primeiro lugar, apresentar sua impugnação. Já do indeferimento liminar, evidentemente, deve caber recurso por parte do postulante da gratuidade. Igualmente, a decisão que resolve o incidente de impugnação da gratuidade, mantendo ou revogando o benefício, deve ser passível de recurso.

Quanto ao recurso cabível, melhor se mostra o agravo. A atual Lei n. 1.060/50 contém regra anômala dentro do sistema processual, definindo a apelação como recurso cabível contra um ato que, seguramente, não é uma sentença, pois não põe fim a processo algum. A utilização do agravo se mostra mais técnica e evita discussões que freqüentemente se vê no dia-a-dia do foro, vez que o agravo ora é havido como cabível, ora não, quando a decisão recorrida é proferida nos próprios autos do processo.

Ponto importante deste capítulo é a regra inserta no art. 19. Tal dispositivo assegura a gratuidade processual ao postulante, mesmo diante de decisão denegatória, havendo a interposição de agravo de instrumento. Até que a decisão negativa fique coberta pela preclusão, a parte deve gozar da gratuidade, sob pena de ser violado o seu direito de acesso à justiça, por uma decisão equivocada. Não se trata, aqui, de concessão de efeito suspensivo, no sentido exato do termo, pois nada há para suspender diante de uma decisão que denegue uma pretensão, qualquer que seja ela. A regra estabelece, sim, o princípio pelo qual a parte deve poder gozar da gratuidade, enquanto discute ter direito a ela. Parece-nos absurdo exigir que o pobre pague, por exemplo, as custas do recurso em que pede para ser reconhecido o seu direito de não-pagar. Como, nestes casos, convém que a questão seja resolvida o quanto antes, para continuar usufruindo do benefício a parte deve manejar o recurso de agravo de instrumento, e não o retido. Para a parte contrária, porém, fica a opção entre os dois tipos de agravo, conforme sua conveniência. 
No art. 20, estão previstas sanções, que se limitam aos casos em que ficar evidenciado que a parte agiu maliciosamente, ao postular a gratuidade. Não se deve punir aquele que, razoavelmente, se achando com direito ao benefício, não foi assim considerado pelo juiz. O que se deve sancionar com rigor é a mentira, ou a omissão de fato relevante que o postulante, evidentemente, deva conhecer. Ou, então, aplica-se também a pena quando o requerente, sem esconder sua situação patrimonial avantajada, postula a gratuidade processual em evidente abuso.

$\mathrm{O}$ art. 21, fechando este capítulo, dispõe que a decisão acerca da concessão do benefício está sujeita à preclusão. Como conseqüência, somente fatos supervenientes a ela poderão motivar novo pedido, ou impugnação. Fatos pretéritos, alegados ou-não, não permitem reabrir a questão.

\subsection{Da assistência jurídica}

A assistência juridica consiste na prestação gratuita de serviços jurídicos, podendo ser dividida em assistência judiciária, que é o patrocínio de causa judicial, e em assistência jurídica extrajudicial, consistente no serviço de orientação jurídica. A assistência jurídica não se confunde com a justiça gratuita, que é a isenção do pagamento das despesas decorrentes do processo. A assistência jurídica consiste numa prestação positiva devida pelo Estado ao carente de recursos.

Definida a assistência jurídica, no primeiro capítulo deste título, o segundo capítulo cuida do prestador deste serviço.

Necessário se faz, por primeiro, definir quem está prestando esta atividade, que tem natureza de serviço público, para distingui-lo daqueles que estão ou prestando um favor a pessoas determinadas, ou atuando profissionalmente em favor de pessoas pobres, mas visando a futura remuneração com o recebimento de honorários decorrentes da sucumbência.

Segundo o anteprojeto, presta serviço público de assistência jurídica não-só a Defensoria Pública ou órgão público equivalente, mas também "as entidades privadas que desempenhem esta função como sua finalidade" bem como "os advogados que desempenhem esta função por determinação judicial ou convênio com o Poder Público".

Como ao prestador de assistência jurídica deve ser dado um tratamento diferenciado, quando em juízo, mostra-se coerente equiparar estes dois últimos sujeitos à Defensoria Pública, reconhecendo que sua atividade é igualmente 
um serviço público. Isto porque, em última análise, o tratamento diferenciado é concedido ao pobre por eles atendido, sendo contrário à isonomia privilegiar o carente atendido pelo Estado, em detrimento daquele que, normalmente por insuficiência do serviço oficial, é atendido por órgão não-estatal. O que têm em comum estes sujeitos, elencados no art. 23, é o fato de estarem "de portas abertas" para o público em geral. O serviço está disponível para qualquer um, desde que carente de recursos. Não ocorre, em nenhum dos três casos, a mútua escolha que normalmente opera entre cliente e advogado, fato que se verifica quando o advogado particular atua gratuitamente como um favor dirigido a determinada pessoa, ou visando a honorários ao final da causa. Nada há a desmerecer estes últimos. Apenas não lhes daremos as vantagens concedidas ao prestador de assistência jurídica, pois não há razão para o tratamento diferenciado.

Neste capítulo, em parte retornando ao que dispunha o antigo Estatuto do Advogado, mas indo além de suas disposições, confere-se ao estagiário de direito maior capacidade postulatória, restrita aos casos em que atuar como prestador de assistência jurídica (art. 24).

No art. 25 são enumeradas as facilidades conferidas em juízo ao prestador de assistência jurídica, relativas às intimações, ao prazo dobrado, à proibição de citação na pessoa do patrono e à possibilidade de outorga de mandato por termo nos autos.

Para solucionar interminável controvérsia quanto aos limites do segredo de justiça, o art. 26 autoriza vista dos autos em cartório "às pessoas expressamente autorizadas pelo prestador de assistência juridica", sejam elas inscritas na OAB ou-não. A medida visa a permitir o acompanhamento de processos por estudantes de direito ainda não-inscritos nos quadros da Ordem, facilitando o trabalho do órgão prestador.

Finalmente, o último capítulo trata do acesso do pobre ao órgão prestador de assistência jurídica. Mais uma vez, basta a mera declaração de que preenche as condições da lei, que se presume verdadeira e só pode ser elidida diante de verificação sócio-econômica que demonstre o contrário (art. 32, l, letra "c").

Em caso de inexistência, na localidade, de órgão prestador, ou de recusa deste em atender o carente, este poderá ser atendido pessoalmente, no fórum local, de acordo com o procedimento previsto nos arts. 28 a 31 . Importante será, no futuro, se e quando este anteprojeto vingar, dar a mais ampla publicidade do conteúdo destes artigos, pois a mera presunção de conhecimento da lei, com sua 
publicação no Diário Oficial, não será o bastante para informar o pobre sobre esta possibilidade, que se abre a ele, de pedir assistência jurídica.

Para dar maior segurança de que o carente saberá a quem recorrer, quando réu na ação, o art. 285 insere modificação no corpo do Código de Processo Civil. Inclui-se mais um requisito formal para a validade da citação: "a informação de que o réu, se for pobre, poderá ser defendido gratuitamente por órgão prestador de assistência jurídica, constando do mandado o endereço do órgão oficial, se existir no local, ou indicações de como proceder para obter a assistência na Comarca" É sabido que o réu pobre, uma vez citado, freqüentemente não sabe onde ou a quem se dirigir para ser defendido. Quando chega a um órgão prestador de Assistência Jurídica, muitas vezes já se dirigiu anteriormente ao Serviço Social, à Delegacia, às Igrejas, em prejuízo não-só do prazo para defesa, como também do seu tempo de trabalho e da sua já parca remuneração. A regra, simples de ser cumprida, procura superar o problema e diminuir os casos de revelia motivados, não pelo desinteresse, mas por impossibilidade econômica e falta de informação.

5. O anteprojeto

\section{TITULO I - DA ASSISTENNCIA JURÍDICA INTEGRAL E GRATUITA}

\section{Capítulo I Disposições Gerais}

Art. $1^{\circ} \quad O$ benefício da Assistência Jurídica Integral e Gratuita, previsto no art. $5^{\circ}$, LXXIV, da Constituição Federal, regula-se pelo disposto nesta Lei.

Parágrafo único A Assistência Jurídica Integral e Gratuita compreende:

I a Justiça Gratuita;

II - a Assistência Jurídica.

Art. $2^{\circ}$ Os Poderes Públicos Federal, Estadual e Municipal, independentemente da colaboração que possam receber da Ordem dos Advogados do Brasil e das Faculdades de Direito públicas e privadas, promoverão o acesso à justiça dos carentes de recursos. 
Art. $3^{\circ}$ - A União e os Estados terão o prazo de um ano para criação de um fundo de assistência jurídica, para custeio dos benefícios previstos nesta Lei.

Parágrafo único Serão destinados ao fundo de que trata este artigo, obrigatoriamente, $1 \%$ (um por cento) das custas judiciais arrecadadas pela União ou pelo Estado, além de outras fontes a serem instituídas com sua criação.

\section{Capítulo II do beneficiário}

Art. $4^{\circ} \quad$ Considera-se necessitado, para os fins de concessão de Assistência Jurídica Integral e Gratuita, nos termos desta Lei:

I a pessoa natural, cuja situação econômica não lhe permita pagar as custas e despesas decorrentes do processo e os honorários de advogado, sem prejuízo do sustento próprio ou da família;

II - a pessoa jurídica sem fins lucrativos, de natureza assistencial ou filantrópica, prestadora de serviços gratuitos à comunidade em geral, que não tenha condições financeiras de arcar com as custas e despesas decorrentes do processo e os honorários de advogado, sem prejuízo da sua atividade.

Parágrafo único - $\quad$ O direito à Assistência Jurídica é personalíssimo, não se transmitindo aos sucessores a qualquer título.

\section{TÍTULO II DA JUSTIÇA GRATUITA}

\section{Capítulo I Do beneficio da Justiça Gratuita}

Art. $5^{\circ}$ - O benefício de Justiça Gratuita compreende:

I a dispensa de antecipação das despesas processuais;

II a suspensão da exigibilidade das verbas decorrentes da sucumbência.

$\S 1^{\circ} \quad$ Considera-se despesa processual, para os fins desta lei:

I a taxa judiciária e demais custas processuais devidas ao Estado;

II as despesas de locomoção dos Oficiais de Justiça;

III - as despesas com as publicações no jornal encarregado da divulgação dos atos oficiais; 
IV - as indenizações devidas às testemunhas que, quando empregados, receberão do empregador salário integral, como se em serviço estivessem, ressalvado o direito de regresso contra a Fazenda Pública;

$\mathrm{V}$ os honorários devidos a terceiros, cujos serviços sejam necessários ao processo, tais como peritos, tradutores, intérpretes e depositários;

VI as custas e emolumentos extrajudiciais, relativos a atos necessários para o exercício do direito de ação ou defesa, para a produção de prova, para a prática de atos processuais ou para lhes dar eficácia;

VII as despesas com extração de cópias necessárias para a formação de agravo de instrumento, carta de sentença, carta precatória, formal de partilha, mandado de citação ou intimação, ou para a prática de atos processuais;

VIII as despesas postais;

IX a caução para propositura de ação rescisória;

$\mathrm{X}$ - todas as demais despesas, cujo pagamento seja necessário para o exercício do direito de ação ou defesa, para a produção de prova, para a prática de atos processuais ou para lhes dar eficácia.

$\S 2^{\circ}$ A publicação de editais em jornal, quando determinada em lei, será feita apenas no órgão oficial.

$\S 3^{\circ}$ O juiz concederá parcialmente a Justiça Gratuita para as pessoas não-elencadas nos incisos I e II do artigo anterior, toda a vez que o pagamento integral das custas e despesas constituir óbice ao acesso à justiça.

Art. $6^{\circ}$ - Quando a falta de recursos do necessitado, mesmo gozando dos benefícios relacionados no artigo anterior, constituir óbice ao seu comparecimento ou à prática de atos processuais, o juiz determinará as providências necessárias para permitir o acesso à justiça, conforme as peculiaridades do caso, podendo requisitar bens e serviços públicos ou particulares, ressalvado a estes últimos o direito de regresso contra a Fazenda Pública.

Art. $7^{\circ}$ - O benefício da Justiça Gratuita compreende todos os atos do processo, em todos os graus de jurisdição, não sendo motivo para sua rejeição o tipo de pedido formulado pelo autor, a natureza do direito material envolvido no litígio nem o fato de ser o requerente defendido por advogado particular.

Art. $8^{\circ}$ Sendo vencedor da causa o beneficiário de Justiça Gratuita, a parte contrária será condenada ao pagamento de honorários advocatícios, nos termos da lei processual, bem como de todas as despesas que não foram antecipadas, valendo a sentença como título executivo judicial em favor do credor. 
Art. $9^{\circ}$ Sendo vencido o beneficiário de Justiça Gratuita, aplica-se o disposto neste artigo.

$\S 1^{\circ} \mathrm{O}$ beneficiário será condenado ao pagamento das despesas adiantadas pela parte contrária e honorários advocatícios, nos termos da lei processual, mas o crédito não será exigível até que o vencido perca a condição legal de necessitado.

$\S 2^{\circ}$ - Se dentro de cinco anos o vencido não perder a condição legal de necessitado, a obrigação será tornada definitivamente inexigível.

$\S 3^{\circ}$-Compete ao credor, em procedimento preparatório a ser desenvolvido segundo o rito previsto nos arts. 801 a 803 , do CPC, provar a perda da condição legal de necessitado, como requisito indispensável para a instauração da execução.

$\S 4^{\circ}$ Será extinto o processo de execução, de ofício ou a requerimento da parte, quando o credor não provar que a obrigação se tornou exigível, nos termos do parágrafo anterior.

$\S 5^{\circ}$ Os créditos devidos ao particular em decorrência da não antecipação de despesas ou da requisição de bens e serviços, serão suportadas pela União, quando a causa houver tramitado nas Justiças Federais ou nas Justiças Estaduais, nos casos previstos no art. $109, \S 3^{\circ}$, da Constituição Federal, ou pelo Estado, quando a causa houver tramitado perante a Justiça Estadual, valendo a sentença como título executivo judicial em favor do credor. Com a instituição do fundo de que trata o art. $3^{\circ}$ desta Lei, o pagamento poderá ser feito administrativamente, sem prejuízo do direito do credor de promover a execução judicial.

$\S 6^{\circ}$ - Aplica-se o disposto no parágrafo anterior quanto aos honorários do advogado do beneficiário, se este não for atendido por órgão oficial ou por agente prestador remunerado pelo poder público, caso em que o juiz, na sentença, fixará o valor dos honorários.

\section{Capítulo II Do procedimento para concessão de Justiça Gratuita}

Art. 10 - O pedido de Justiça Gratuita independe de forma específica, podendo ser feito na própria petição inicial, contestação, conjuntamente com outro ato processual ou em petição autônoma a ser juntada nos próprios autos 
do processo, mediante declaração de que é necessitado, nos termos do art. $4^{\circ}$, incisos I e II desta Lei.

Parágrafo único Presume-se verdadeira, até prova em contrário, a declaração a que se refere este artigo.

Art. 11 pedido de Justiça Gratuita será deferido de plano pelo juiz; havendo dúvida quanto ao seu cabimento, o juiz determinará que o requerente preste esclarecimentos quanto aos pontos duvidosos, no prazo de 5 (cinco) dias, decidindo em seguida.

Parágrafo único A menos que, em razão das provas já constantes dos autos ou das manifestações do requerente, ficar inequivocamente demonstrado que o requerente não preenche a condição legal de necessitado, o benefício deverá ser deferido.

Art. 12 - A parte contrária poderá impugnar o pedido de Justiça Gratuita a qualquer tempo, em petição autônoma, que será autuada em apartado, sem suspender o processo, alegando a inexistência ou perda superveniente da condição de necessitado e especificando as provas que pretende produzir.

Art. 13 Sobre a impugnação, será ouvido o requerente, no prazo de 5 (cinco) dias, especificando as provas que pretende produzir.

Art. 14 Havendo necessidade de prova oral, o juiz designará audiência para esse fïm.

Art. 15 - Colhidas as provas, ou não havendo provas a serem produzidas, o juiz decidirá o incidente.

Art. 16 A decisão que conceder a Justiça Gratuita atinge todas as antecipações de despesas ainda não efetuadas pelo beneficiário, mesmo que decorrentes de fatos ou determinações anteriores ao requerimento da gratuidade.

Art. 17 Da decisão que concede de plano o benefício não cabe recurso.

Art. 18 Da decisão que indefere de plano o benefício, ou da que resolve o incidente, caberá o recurso de agravo.

Art. 19 Havendo a interposição de recurso contra o indeferimento do benefício, o requerente gozará da Justiça Gratuita até sua decisão final; mas, neste caso, o recorrente não poderá se utilizar do agravo retido.

Art. 20 A decisão que acolher a impugnação cominará multa ao requerente, em favor da parte contrária, de até dez vezes o valor das despesas, se: 
I - houver alegação de fato inverídico ou a omissão de fato relevante pelo requerente;

II - o pedido de gratuidade for notoriamente improcedente.

Art. 21 Preclusa a questão da concessão da Justiça Gratuita, novo pedido ou impugnação só poderão ser fundados em fatos supervenientes.

\section{TÍTULO III - DA ASSISTÊNCIA JURÍDICA}

Capítulo I Do beneficio da Assistência Jurídica

Art. 22 - O benefício da Assistência Jurídica compreende:

a) a prestação de assistência judiciária aos legalmente necessitados, em processo judicial ou administrativo;

b) a prestação de assistência judiciária aos réus revéis em processo criminal;

c) a prestação de orientação jurídica extrajudicial aos legalmente necessitados.

Capítulo II Do prestador da assistência juridica

Art. 23 Consideram-se prestadores de assistência jurídica, para os fins desta Lei:

I a Defensoria Pública, ou órgão público que exerça função equivalente;

II - as entidades privadas que desempenhem esta função como sua finalidade;

III - os advogados que desempenhem esta função por determinação judicial ou convênio com o Poder Público.

Art. 24 Os acadêmicos de Direito inscritos no quadro de estagiários da OAB poderão atuar na prestação da assistência jurídica, nos termos deste artigo.

$\S 1^{\circ}$ - Os estagiários atuarão no processo sempre em conjunto com advogado, e sob a supervisão deste. 
$\S 2^{\circ}$ Os estagiários poderão praticar todos os atos do processo isoladamente, salvo os seguintes, que deverão ser praticados por advogado, podendo o estagiário subscrevê-los em conjunto:

I petição inicial;

II queixa-crime;

III - contestação;

IV defesa prévia;

V exceção de suspeição ou de impedimento;

VI memoriais e alegações finais;

VII recursos e contra-razões de recurso.

$\S 3^{\circ}$ - Mediante autorização do advogado da causa, com referência nominal ao estagiário, este poderá atuar nas audiências de conciliação, instrução e julgamento, bem como fazer sustentação oral em qualquer instância ou tribunal.

$\S 4^{\circ}$ A autorização a que se refere o parágrafo anterior poderá ser passada previamente, por escrito, ou oralmente, se o advogado estiver presente ao ato.

Art. 25 Ao prestador de assistência judiciária aplicam-se as seguintes disposições:

I o prestador designado no art. 23, inciso I, desta Lei, será intimado pessoalmente de todos os atos do processo, em todos os graus de jurisdição;

Il - o prestador designado no art. 23, inciso II, desta Lei, poderá ser intimado por publicação no órgão oficial, mas da intimação deverão constar obrigatoriamente, além dos requisitos previstos na lei processual, sob pena de nulidade:

a) o nome da entidade prestadora;

b) o nome dos advogados, estagiários e estudantes de Direito que representam o assistido, podendo o juiz limitar, ao máximo de 5 (cinco), os nomes que constarão da publicação; havendo tal limitação, deverão constar da intimação os nomes que a parte houver indicado, dos quais ao menos 1 (um) deverá ser advogado;

III - ser-lhe-ão contados em dobro todos os prazos processuais para manifestação nos autos, em todos os graus de jurisdição; o prazo em dobro para a resposta do réu independe de prévio requerimento dentro do prazo normal;

IV não se fará a citação do assistido na pessoa do seu patrono, nas hipóteses de reconvenção, oposição, embargos à execução, embargos de terceiro; 
poderá o patrono, contudo, aceitar expressamente a citação, a fím de permitir o prosseguimento da ação principal;

V o mandato poderá ser outorgado por termo nos autos; será dispensada a juntada de instrumento de mandato quando a parte for representada em juízo pela Defensoria Pública, ou órgão público que exerça função equivalente, ressalvados:

a) os atos previstos no art. 38 do Código de Processo Civil;

b) o requerimento de abertura de inquérito por crime de ação privada, a propositura de ação penal privada ou o oferecimento de representação por crime de ação pública condicionada.

Art. 26 - Nos processos que correm em segredo de justiça, além das partes e seus procuradores, será autorizada a vista dos autos em cartório às pessoas expressamente autorizadas pelo prestador de assistência jurídica.

\section{Capítulo III - Do acesso do necessitado ao prestador de Assistência Jurídica}

Art. 27 - A simples declaração do necessitado de que preenche as condições estabelecidas no art. $4^{\circ}$ desta Lei lhe permitirá o acesso ao órgão oficial prestador de assistência jurídica.

Art. 28 - Não havendo, na localidade, órgão oficial prestador de assistência jurídica, ou havendo recusa no atendimento, o necessitado poderá se dirigir ao fórum local, onde, na falta de outra determinação pela lei de organização judiciária, será atendido:

I pelo escrivão do primeiro ofício cível, se na Comarca houver varas especializadas;

II pelo escrivão do primeiro ofício, se na Comarca houver mais de uma vara, sem especialização;

III pelo escrivão do ofício único.

Art. 29 - O escrivão tomará por termo a declaração de pobreza e os motivos que levaram o necessitado a procurar a assistência, apresentando-a ao juiz, independentemente de autuação, no prazo de 24 (vinte e quatro) horas.

Art. 30 - O juiz apreciará o pedido de gratuidade, com a oitiva do necessitado, se for o caso, e decidirá o pedido no prazo de 24 (vinte e quatro) horas. 
Art. 31 Deferido o pedido, o juiz ordenará o atendimento do carente pelo órgão oficial, se existente no local, ou pela Ordem dos Advogados do Brasil, que indicará advogado para atender ao beneficiário.

Parágrafo único Nos municípios em que não existem subseções da Ordem dos Advogados do Brasil, o próprio juiz nomeará advogado para prestar a assistência jurídica.

Art. 32 São justos motivos para a recusa no atendimento ao carente:

I pelo Defensor Público ou pelo advogado indicado:

a) ter sido constituído pela parte contrária, ou ter-lhe dado orientação a respeito dos fatos da causa;

b) já ter orientado o necessitado, manifestando sua opinião contrária ao direito que pretende pleitear;

c) a realização de verificação sócio-econômica, que demonstre que o postulante não preenche a condição legal de necessitado.

II - pelo advogado indicado:

a) estar impedido de exercer a advocacia ou não a estar exercendo por mais de 3 (três) anos;

b) ter necessidade de se ausentar da sede do juízo para atender a outro mandato anteriormente outorgado ou para defender interesses próprios inadiáveis.

Parágrafo único - Será preferido para o atendimento do necessitado o advogado por ele indicado e que declare aceitar o encargo.

Art. 33 - $\mathrm{O}$ art. 285 da Lei n. 5.869, de 11.01 .73 (Código de Processo Civil), passa a vigorar com a seguinte redação:

Art. 285 Estando em termos a petição inicial, o juiz a despachará, ordenando a citação do réu, para responder; do mandado constará obrigatoriamente, sob pena de nulidade:

I - que não sendo contestada a ação, se presumirão aceitos pelo réu, como verdadeiros, os fatos articulados pelo autor;

II - a informação de que o réu, se for pobre, poderá ser defendido gratuitamente por órgão prestador de assistência jurídica, constando do mandado o endereço do órgão oficial, se existir no local, ou indicações de como proceder para obter a assistência na Comarca.

Art. 34 Fica revogada a Lei n. 1.060, de 5 de fevereiro de 1950. 
Art. 35 - Esta Lei entra em vigor 60 (sessenta) dias após sua publicação.

São Paulo, outubro de 1997 